\title{
The training of licensed nurses: the valuation of teaching in secondary-level technical professional education
}

\author{
Adriana Katia Corrêa' \\ ORCID: 0000-0003-1496-6108 \\ Maria José Clapis" \\ ORCID: 0000-0002-2896-3808 \\ Rosa Maria Rodrigues"'I \\ ORCID: 0000-0002-7047-037X \\ Solange de Fatima Reis Conterno ${ }^{\prime \prime \prime}$ \\ ORCID: 0000-0003-2493-8071
}

'Universidade de São Paulo, Escola de Enfermagem de Ribeirão Preto. Coordinator of the Brazilian National Forum of Undergraduate Nursing. Director of Education at ABEn-SP. Member of the Permanent Commission for High School Technical Professional Education of the ABEn-Nacional Education Center. São Paulo, São Paulo, Brazil.

"Universidade de São Paulo, Escola de Enfermagem de Ribeirão Preto. Member of the Brazilian National Forum of Undergraduate Nursing and Participating Member of the Advisory Group of Undergraduate Nursing - Education Board - ABEn-SP. São Paulo,

São Paulo, Brazil.

I'Universidade Estadual do Oeste do Paraná, College of Nursing. Member of the National Forum of Undergraduate Nursing.

Cascavel, Paraná, Brazil.

How to cite this article: Corrêa AK, Clapis MJ, Rodrigues RM, Conterno SFR. Licensed nurses' training: the valuation of teaching in secondary-level technical professional education. Rev Bras Enferm.2022;75(2):e750201. https://doi.org/10.1590/0034-7167.2022750201

Corresponding author: Adriana Katia Corrêa adricor@eerp.usp.br
Some nursing professionals, in Brazil, have training as a nurse and licensee, contemplating the possibility of acting as a nurse in the Health Care Network and in any scenario, in which there is the insertion of activities that require their performance and as a professor in secondary-level technical professional education (EPTNM), a modality of basic education.

This training has been offered, especially in public universities, by bachelor's degree and compound degree in an integrated way, with knowledge of biological and human sciences, mainly in the field of education. This composition may favor the appropriation of a solid base of knowledge that structure professional praxis. This is the possibility of training involving two professional fields: nursing and teaching.

Historically, there is fragile policy of professor training for EPTNM in Brazil. The valorization of the insertion of professors with consistent training who contribute to emancipatory education represents a contradiction. On the one hand, in the conservative way, it is enough the professional of a given area that will teach technical workers to do so. On the other hand, in a transformative perspective, professors' work with a broad view, in the political-social, pedagogical and technical dimensions, will enhance the status quo questioning.

It is in this perspective that it is up to the training to assure health workers not only the capacities for the realization of human care, but also to encourage a critical awareness of themselves and their reality, which also implies taking as north the training work on the Sanitary Reform foundations that, in summary, are present in the binomial health-democracy ${ }^{(1)}$.

Given the numerical contingent of nursing assistants and technicians who make up the majority of the health team, licensed nurses' work in the defense of a training project in favor of social needs, the Unified Health System (SUS - Sistema Único de Saúde) and human dignity is extremely important. This defense is even more relevant in the current political-economic scenario, in which the neoliberal ideology advances, shrinking social policies in favor of commodification, intensifying social inequalities. Exercising teaching implies assuming a project of education, health and society that needs to be translated into political-pedagogical decisions that go beyond the classroom and the specific contents to be taught, inserting itself in broader social relations.

This means that there is a requirement that EPTNM professors have a training as a socially referenced nurse with consistent knowledge in different dimensions, which allow the commitment to health care based on SUS principles. It is also necessary that nurse professors have extensive knowledge about epistemological aspects of education, education policies and curriculum as historical production and didactic developments arising from the specificity of EPTNM and in the area of health/nursing.

These ideas about the knowledge of the educational field meet the categorization of knowledge that every professor needs to master, and should be part of their training process: attitudinal knowledge; contextual-critical; specific; pedagogical and didactic-curricular ${ }^{(2)}$. Forwarding the proposal of professor education, however, in the direction outlined here, has been demanding processes of confrontation and resistance, considering the current policies of professor education for basic education with a predominantly 
pragmatic nature, devaluation of professors' intellectual autonomy and decision-making; as well as the position of the Brazilian National Council of Education/MEC, which, when analyzing the document that proposes new Curriculum Guidelines for Nursing, in April 2021, disregards the degree.

Licensed nurses'training does not, by itself, transform the concrete working conditions of professors or the training project proposed in technical schools, since any transformation of the educational system implies structural and conjuncture change in the direction of a democratic, just and egalitarian society ${ }^{(3)}$. However, dialectically, human formation, understood as that which guarantees workers a complete formation that provides reading the world and acting as a citizen integrated into political society ${ }^{(4)}$, is a fundamental dimension of social transformation.

\section{REFERENCES}

1. Bomfim MI, Rummert SM, Goulart VM. Educação profissional em saúde: o sentido da escola pública e democrática. Rev COCAR [Internet]. 2017[cited 2021 Oct 04];3(ed-Esp):322-43. Available from: https://paginas.uepa.br/seer/index.php/cocar/article/viewFile/1294/812

2. Saviani D. Educação escolar, currículo e sociedade: o problema da Base Nacional Comum Curricular. Movimento Rev Educ. 2016;3(4):54-84. https://doi.org/10.22409/mov.v0i4.296

3. Associação Nacional Pela Formação dos Profissionais da Educação (Anfope). Documento final do XX Encontro Nacional da Anfope - Política de formação e valorização dos profissionais da educação: resistências propositivas à BNC da formação inicial e continuada[Internet]. 2021 [cited 2021 Oct 04]. Available from: http://www.anfope.org.br/wp-content/uploads/2021/04/20\%E2\%81\%B0-ENANFOPE\%E2\%80\%93-Documento-Final-2021.pdf

4. Ciavatta M. A formação integrada: a escola e o trabalho como lugares de memória e de identidade. In: Frigotto G, Ciavatta M, Ramos M. Ensino Médio Integrado: concepções e contradições. 3a ed. São Paulo: Cortez; 2012. p 83-106. 